\title{
Serological and molecular detection of Toxoplasma gondii in dogs of urban and rural areas of Cuiaba, Mato Grosso
}

\section{Deteç̧ão sorológica e molecular de Toxoplasma gondii em cães de áreas urbanas e rurais de Cuiabá, Mato Grosso}

\author{
Eveline da Cruz Boa Sorte ${ }^{1}$; Arleana do Bom Parto Ferreira de Almeida ${ }^{2}$; \\ Felipe Augusto Constantino Seabra da Cruz³ ; Naiani Domingos Gasparetto ${ }^{4}$; \\ Isabela de Godoy"; Valéria Dutra ${ }^{2}$; \\ Maria Regina Reis Amendoeira ${ }^{5}$; Valéria Régia Franco Sousa ${ }^{2 *}$
}

\begin{abstract}
This study aimed to determine the prevalence of Toxoplasma gondii infection using serological and molecular analyses in dogs from Cuiabá, a municipality of the Brazilian Cerrado, and the associated factors involved in the transmission cycle. A cross-sectional study was conducted with dogs from the rural and urban areas of Cuiabá (Mato Grosso) from February 2010 to January 2011, and antibodies and the DNA of Toxoplasma gondii were evaluated using indirect immunofluorescence (IFA) and polymerase chain reaction (PCR). In the study, a total of 269 dogs were evaluated using IFA considering positive titer threshold of $\geq 16$ and buffy coat PCR. Of the 269 dogs surveyed, $48.7 \%$ had anti-Toxoplasma gondii antibodies according to IFA, and $15.6 \%$ had the parasite's DNA. The seroprevalence was $62.4 \%$ in the rural districts and $40.4 \%$ in the urban areas, and the difference between these areas was significant $(\mathrm{p}=0.0007)$. The most common levels of antibody titers were 256 in $51(39 \%)$ dogs, followed by 1024 in $37(28.2 \%)$ dogs. The infectious agent was associated with breed, age, access to the street and the environment in which the animal lived $(\mathrm{p}<0.05)$. The serological and molecular results showed that $T$. gondii infection is active in the canine population in the rural and urban areas of Cuiabá, with a higher risk in dogs residing in rural areas.
\end{abstract}

Key words: Dog, associated factors, PCR, serology, toxoplasmosis

\section{Resumo}

Este artigo teve por objetivo determinar a soroprevalência da infecção por Toxoplasma gondii através de análise sorológica e molecular em cães de Cuiabá, município do cerrado brasileiro, associando com os fatores de risco envolvidos na cadeia de transmissão. Estudo transversal foi conduzido com cães de áreas rurais e urbanas de Cuiabá (Mato Grosso), entre fevereiro de 2010 a janeiro de 2011, através da pesquisa de anticorpos por imunofluorescência indireta e DNA de Toxoplasma gondii. Foram avaliados no estudo um total de 269 cães por IFI, considerando reagente cães com título $\geq 16$ e por PCR de capa

Médica Veterinária Autônoma, M.e em Ciências Veterinárias, Cuiabá, MT, Brasil. E-mail: evelinesorte@hotmail.com

2 Profs. Drs., Dept ${ }^{\circ}$ de Clínica Médica Veterinária, Faculdade de Agronomia, Medicina Veterinária e Zootecnia, UFMT, Cuiabá, MT, Brasil. E-mail: arleferreira@gmail.com; valdutra@ufmt.br; valeriaregia27@gmail.com

3 Discente do curso de Mestrado do Programa de Pós-Graduação em Ciências Veterinárias, UFMT, Cuiabá, MT, Brasil. E-mail: felipeseabradacruz@hotmail.com

4 Discentes do curso de Doutorado do Programa de Pós-Graduação em Ciências Veterinárias, UFMT, Cuiabá, MT, Brasil. E-mail: naianigasparetto@hotmail.com; belinhagodoy@hotmail.com

5 Pesquisadora, Laboratório de Toxoplasmose, Fundação Oswaldo Cruz, FIOCRUZ, Rio de Janeiro, RJ, Brasil. E-mail: amendoei@ ioc.fiocruz.br

* Author for correspondence 
leucocitária. Dos 269 cães pesquisados, 48,7\% apresentaram anticorpos anti-Toxoplasma gondii pela IFI e 15,6\% DNA do parasito. Os bairros localizados em ambiente rural apresentaram uma soroprevalência de $62,4 \%$ e os urbanos de $40,4 \%$, dados estes estatisticamente significativos ( $\mathrm{p}=0,0007$ ). Os títulos mais frequentemente observados foram de 256 em 51 (39\%) cães, seguido por 1024 em 37 (28,2\%) cães avaliados. A infecção pelo agente esteve associada a raça, idade, acesso à rua e ao ambiente em que o animal vivia $(\mathrm{p}<0,05)$. Os resultados sorológicos e moleculares permitiram inferir que a infecção por $T$. gondii encontra-se ativa na população canina nas regiões rurais e urbanas do município de Cuiabá, com risco maior em cães residentes em áreas rurais.

Palavras-chave: Cão, fatores de risco, PCR, sorologia, toxoplasmose

\section{Introduction}

Toxoplasma gondii is an obligate intracellular parasite that belongs to the Phylum Apicomplexa and infects approximately one-third of the human population and various animal species, including dogs (REID et al., 2012). In humans, toxoplasmosis is a clinical disease that is rare; however, in immunosuppressed patients with cancer and AIDS, this disease is recognized as a major cause of death (MARTINS; VIANA, 1998). Similarly, in dogs, the disease is often associated with immunosuppressive diseases such as canine distemper (MORETTI et al., 2002).

In Brazil, the prevalence of infection in humans is more than 68\% (SROKA et al., 2010; SANTOS et al., 2009) depending on the study area, whereas studies in dogs have shown infection rates ranging from $20.8 \%$ (ROMANELLI et al., 2007) to $88 \%$ (SANTOS et al., 2009). A high prevalence of toxoplasmosis in dogs is correlated with a highly contaminated environment, as it facilitates infection in these species because of eating habits and ground contact (GARCIA et al., 1999).

To confirm the risk factors of $T$. gondii infection in dogs, this study aimed to determine the presence of anti- $T$. gondii and the parasite's DNA in pet dogs in the urban and rural areas of Cuiaba, a Brazilian cerrado municipality.

\section{Materials and Methods}

A cross-sectional study was conducted from February 2010 to January 2011 in rural (Barreiro
Branco and Coxipó do Ouro) and urban (Osmar Cabral and Jardim União) areas in Cuiaba $\left(15^{\circ} 35^{\prime} 56^{\prime \prime} \mathrm{S}\right.$ and $\left.56^{\circ} 06^{\prime} 01^{\prime} \mathrm{W}\right)$, a city located in the south-central state of Mato Grosso in Brazil's cerrado. The city covers 3362.755 square kilometres, is at an altitude of 165 metres above the sea level, has a warm tropical and sub-humid climate, has an average annual rainfall of $1750 \mathrm{~mm}$ and temperature of $43^{\circ} \mathrm{C}$ to $14{ }^{\circ} \mathrm{C}$ and has a population of 551,098 inhabitants (IBGE, 2011) and 96502 dogs (CCZ, 2007).

Based on a sample calculation considering a disease prevalence of $22.3 \%$ (MOURA et al., 2009), 95\% confidence intervals and an error rate of $5 \%, 269$ dogs of various breeds and ages were examined. The samples were taken from each street block from every 5 homes, and home visits were conducted. After an explanation of the study was provided and consent of the owners was obtained, a questionnaire was administered to obtain data on the following: sex, breed, age, eating habits, presence of cats, street access and features of the floor where the animal lived. From each dog, blood samples with and without anticoagulant were collected by puncturing the cephalic or jugular vein and stored at $-20^{\circ} \mathrm{C}$.

To perform the indirect immunofluorescence (IFA), we used antigen tachyzoites of $T$. gondii (RH strain) at a concentration of $1 \times 10^{7} \mathrm{taq} / \mathrm{mL}$ and conjugated anti-IgG dog (Sigma Aldrich ${ }^{\circledR}$ ) (CAMARGO, 1964). Reagents were used in the dog samples with a titration threshold of $\geq 1: 16$ (MOURA et al., 2009), and the samples were compared with positive and negative controls. 
To extract DNA from the blood samples, we used the phenol-chloroform-isoamyl method (SAMBROOK et al., 1989). The polymerase chain reaction (PCR) was performed using TOXO 1 oligonucleotides: 5'-GGAACTGCATCCGTTCATGAG-3' and TOXO 2: 5'-TCTTTAAAGCGTTCGTGGTC-3', which amplify a DNA fragment of 194 bp (BURG et al., 1989).

The epidemiological variables were analysed using the chi-square test and Fisher's exact test ( $p$ $<0.05$ ) based on the IFA as the standard technique. The Epi Info version 6 (CDC) program was used to perform the analyses using a statistical significance level of $5 \%$.

This research followed the Animal Experimentation Ethical Principles adopted by the Brazilian Society of Laboratory Animal Science (SBCAL) and was approved by the Ethics Committee for Animal Research (CEPA) -UFMT under the Protocol $N^{\circ} 23108.014445 / 10-7$.

\section{Results}

Of the 269 samples tested, we found a prevalence of $131(48.7 \%)$ cases of infection that were reactive according to IFA and $42(15.6 \%)$ that were positive according to PCR, which resulted in a total of 153 (56.9\%) dogs with the infection. Of the 42 positive PCR results, 20 cases also had titers of antibodies against $T$. gondii.

The seroprevalence was $62.4 \%$ in the rural neighbourhoods and $40.4 \%$ in the urban areas, and the difference between these areas was significant $(\mathrm{p}=0.0007)$ (Figure 1).

Figure 1. Distribution of dogs with Toxoplasma gondii in city of Cuiabá, Mato Grosso, Brazil.

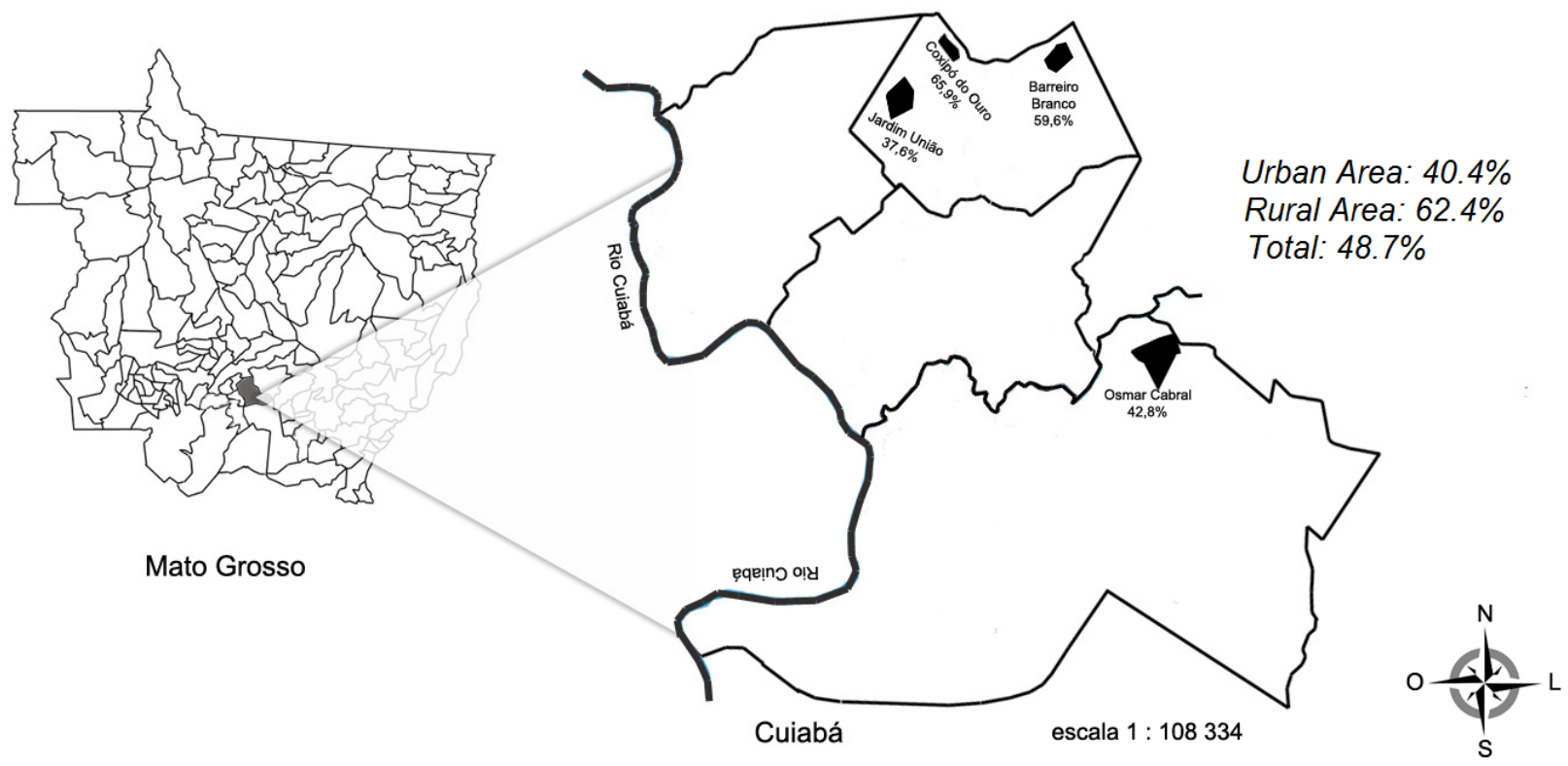

The antibody titers in seropositive dogs were as follows: 16 in 7 dogs (5.3\%); 64 in 26 dogs (19.8\%); 256 in 51 dogs (39\%); 1024 in 37 dogs $(28.2 \%)$; and 4096 in 10 dogs (7.7\%).

On physical examination, 58 (44.3\%) dogs infected with $T$. gondii showed clinical signs during the home visit, including weight loss (20.6\%), generalized lymphadenopathy (16\%), splenomegaly (15.2\%), uveitis and conjunctivitis $(11.4 \%)$. However, these signs were observed in $13.8 \%, 22.5 \%, 8 \%$, and $13.8 \%$, of non-reactive dogs, respectively. 
There was no sex predisposition to infection with T. gondii $(\mathrm{p}=0.95)$, despite the greater percentage of male dogs with antibodies against the agent. However, a significant association was observed between infection and dogs older than six years $(\mathrm{p}=$ 0.03 ) regardless of breed $(p=0.04)$ (Table 1$)$.
Of the dogs that were seropositive, 27 (20.6\%) ate raw meat mixed with feed and / or human food leftovers, and 48 dogs (36.6\%) shared the same environment with cats. Free access to the street was significantly associated with infection $(\mathrm{p}=0.03)$ (Table 1).

Table 1. Association between the variables and the presence of anti-Toxoplasma gondii antibodies in dogs in the city of Cuiaba - Mato Grosso.

\begin{tabular}{|c|c|c|c|c|c|}
\hline \multirow{2}{*}{ Variables } & \multicolumn{3}{|c|}{ Total } & \multirow{2}{*}{ Odds Ratio } & \multirow{2}{*}{ CI } \\
\hline & Positive & $\%$ & $\mathbf{P}$ & & \\
\hline \multicolumn{6}{|l|}{ Breed } \\
\hline SRD & 115 & 87.8 & $0.04^{\mathrm{a}}$ & 2.08 & $1.03-4.24$ \\
\hline CRD & 16 & 12.2 & & & \\
\hline \multicolumn{6}{|l|}{ Sex } \\
\hline Male & 65 & 49.6 & 0.95 & - & - \\
\hline Female & 66 & 50.4 & & & \\
\hline \multicolumn{6}{|l|}{ Age groups } \\
\hline$<3$ years & 63 & 42 & $0.03^{\mathrm{a}}$ & $2.14 *$ & $1.03-4.24$ \\
\hline $3-6$ years & 37 & 54.4 & & & \\
\hline$>6$ years & 31 & 60.8 & & & \\
\hline \multicolumn{6}{|l|}{ Diet } \\
\hline Commercial & 22 & 16.8 & & & \\
\hline Home-cooked & 30 & 22.9 & 0.46 & - & - \\
\hline Raw meat & 27 & 20.6 & & & \\
\hline Mixed & 52 & 39.7 & & & \\
\hline \multicolumn{6}{|l|}{ Contact with cats } \\
\hline Yes & 48 & 36.6 & 0.10 & - & - \\
\hline No & 83 & 63.4 & & & \\
\hline \multicolumn{6}{|l|}{ Access to the street } \\
\hline Yes & 105 & 80.2 & $0.03^{\mathrm{a}}$ & 1.89 & $1.04-3.44$ \\
\hline No & 26 & 19.8 & & & \\
\hline \multicolumn{6}{|l|}{ Area } \\
\hline Urban & 68 & 51.9 & $0.00^{\mathrm{a}}$ & 2.44 & $1.42-4.18$ \\
\hline Rural & 63 & 48.1 & & & \\
\hline
\end{tabular}

a Statistical significance 5\%; SRD - Without defined Breed; CRD - With defined Breed.

In urban areas, there was a significant difference in the number of seropositive dogs between the types of ground floor (mixed (cemented and ground) and cement only) $(\mathrm{p}=0.01)$. However, in the countryside, no seropositive dogs lived in a cemented or mixed environment but instead lived on predominantly dirt floors.

\section{Discussion}

The prevalence of $56.9 \%$ of dogs with a $T$. gondii infection is greater than the $35 \%$ prevalence (GRÖSZ et al., 2002) found between 1997 and 1998 in the sample municipality. This difference may be related to the sample in this study, which included urban and rural areas. In addition to the technique employed, we used two diagnostic techniques with 
different principles. The use of PCR for canine surveys of toxoplasmosis has not been described; however, this methodology (KOMPALIC-CHRIST et al., 2005) using blood samples is able to distinguish acute infections that result in parasitemia, in addition to confirming the transmission cycle of the disease in these environments.

In the serological analysis, high titers of antibodies were detected, in which titers of 256 and 1024 were the most common, and these values suggest chronic infection in most animals (CAMARGO, 1975). This finding differs from the results of other authors (DREER et al., 2013) who found that most animals had low titers. High titers can be justified if highly immunogenic and minimally cystogenic strains lead to the emergence of high antibody levels without clinical signs (DUBEY et al., 1995), an aspect that could explain the high incidence of clinically healthy seropositive dogs found in this study. The clinical signs presented by the dogs were weight loss, lymphadenopathy, splenomegaly and ophthalmic changes, which have also been described by other authors (BRESCIANI et al., 1999; ABREU et al., 2001; MORETTI et al., 2002).

The prevalence depends on the presence of predisposing factors (BARBOSA et al., 2003), which explain the varying prevalence in the literature (SOUZA et al., 2003; CAÑÓN -FRANCO et al., 2004; AZEVEDO et al., 2005; ROMANELLI et al., 2007; MOURA et al., 2009) and suggests the risk to the human population. The factors that were significantly associated with $T$. gondii infection were the following: free access to the street (twofold increased chance of infection) and age older than six years compared to dogs younger than three years (regardless of breed). These factors may result from the management of these animals, as they are probably exposed more to the source of infection, such as rodents and oocysts eliminated by cats, and older animals have a longer exposure to the agent compared to younger dogs (MINEO et al., 2004; LANGONI et al., 2006; SILVA et al., 2009).
The presence and close contact with cats is an important aspect in the epidemiology of canine toxoplasmosis due to environmental contamination, as cats prefer defecating in an environment that contains soil (SANTOS et al., 2009). This factor may explain why dirt only and mixed environments were risk factors of infection in the dogs in this study $(p=0.01)$. However, the presence of cats was not considered a potential risk factor of canine infection. Similarly, diet was not related to risk of infection, although this variable is considered an important risk factor in the epidemiology of toxoplasmosis (ARAÚJO et al., 2001).

Climate change, sanitation, and, most importantly, cultural population can affect the prevalence of $T$. gondii infection and contribute to the development and transmission of the parasite in the environment (FERREIRA et al., 2014). The districts in this study did not have sewage systems, and public garbage collection was irregular. These characteristics may have enabled the high prevalence of infected dogs in these places due to the exposure of the dogs to waste and environmental contamination with organic residue buildup.

\section{Conclusion}

The serological and molecular results revealed that infection with $T$. gondii is active in the canine population in the rural and urban areas of Cuiabá, with a higher risk of infection in rural areas, in adult dogs and in those dogs with free access to the street.

\section{Acknowledgments}

The authors thank Professor Daniel Moura de Aguiar, UFMT, for providing the control serum.

\section{References}

ABREU, C. B.; NAVARRO, I. T.; BALARIN, M. R. S.; BRACARENSE, A. P. F. R. L.; MARANA, E. R. M.; TRAPP, S. M.; FUGINAKA, C. A.; PRUDÊNCIO, L. B.; MATOS, M. R., TSUTSUI, V. S. Aspectos clínicos, 
patológicos e sorológicos da toxoplasmose experimental em cães jovens. Semina Ciências Agrárias, Londrina, v. 22, n. 2, p. 123-130, 2001.

ARAÚJO, D. A.; SILVA, V. A.; ZANETTE, D. F.; SILVA, D. R.; CORREA, N. A. B.; VESLASQUEZ, L. G. Investigação dos fatores associados à infecção pelo Toxoplasma gondii em cães e seres humanos de Porto Figueira, PR. Veterinária e Zootecnia, Botucatu, v. 18, n. 1, p. 98-111, 2001.

AZEVEDO, S. S.;BATISTA, C.S.A.;VASCONCELLOS, S. A.; AGUIAR, D. M.; RAGOZO, A. M. A.; RODRIGUES, A. A. R.; ALVES, C. J.; GENNARI, S. M. Seroepidemiology of Toxoplasma gondii and Neospora caninum in dogs from the state of Paraíba, Northeast region of Brazil. Research in Veterinary Science, Kansas City, v. 79, n. 1, p. 51-56, 2005.

BARBOSA, M. V. F.; GUIMARÃES, J. E.; ALMEIDA, M. A. O.; GONDIM, L. F. P.; REGIS, G. B. Frequência de anticorpos IgG anti- $T$. gondii em soros de cães errantes da cidade de Salvador, Bahia. Brazilian Journal of Veterinary Research and Animal Science, São Paulo, v. 40, n. 6, p. 457-465, 2003.

BRESCIANI, K. D. S.; COSTA, A. J.; TONIOLLO, G. H.; SABATINI, G. A.; MORAES, F. R.; PAULILLO, A. C.; FERRAUDO, A. S. Experimental toxoplasmosis in pregnant bitches. Veterinary Parasitology, Amsterdam, v. 86, n. 2, p. 143-145, 1999.

BURG, J. L.; GROVE, C. M.; POULETTY, P.; BOOTHROYD, J. C. Directed and sensitive detection of a pathogenic protozoan, Toxoplasma gondii, by polymerase chain reaction. The Journal of Clinical Microbiology, Washington DC, v. 27, n. 8, p. 1787-1792, 1989.

CAMARGO, M. E. Diagnóstico sorológico da toxoplasmose na gravidez. Revista da Associação Médica Brasileira, São Paulo, v. 21, n. 11, p. 341-346, 1975.

Improved technique of indirect immunofluorescence for serological diagnosis. Revista do Instituto de Medicina Tropical de São Paulo, São Paulo, v. 6, n. 3, p. 117-118, 1964.

CAÑÓN-FRANCO, W. A.; BERGAMASCHI, D. P.; LABRUNA, M. B.; CAMARGO, L. M. A.; SILVA, J. C. R.; PINTER, A.; GENNARI, S.M. Occurrence of antiToxoplasma gondii antibodies in dogs in the urban area of Monte Negro, Rondônia, Brazil. Veterinary Research Communications, Utrecht, v. 28, n. 2, p. 113-118, 2004.

CENTRO DE CONTROLE DE ZOONOSES - CCZ. Secretaria Municipal de Saúde. Cuiabá: Censo canino do município de Cuiabá, 2007.
DREER, M. K. P.; GONÇALVES, D. D.; CAETANO, I. C. S.; GERÔNIMO, E.; MENEGAS, P. H.; BERGO, D.; LOPES-MORI, F. M. R.; BENITEZ, A.; FREITAS, J. C.; EVERS, F.; NAVARRO, I. T.; MARTINS, L. A. Toxoplasmosis, leptospirosis and brucellosis in stray dogs housed at the shelter in Umuarama municipality, Paraná, Brazil. Journal of Venomous Animals and Toxins including Tropical Diseases, Botucatu, v. 19, n. 23, p. 1-5, 2013.

DUBEY, J. P.; LAPPIN, M. R.; THULLIEZ, P. Long term antibody responses of cat fed Toxoplasma gondii tissue cysts. The Journal of Parasitology, Lawrence, v. 8, n. 6, p. 1887-893, 1995.

FERREIRA, A. I. C.; BRANDÃO DE MATTOS, C. C.; FREDERICO, F. B.; MEIRA, C. S.; ALMEIDA JÚNIOR, G. C.; NAKASHIMA, F.; BERNARDO, C. R.; PEREIRA-CHIOCCOLA, V. L.; MATTOS, L. C. de. Risk factors for ocular toxoplasmosis in Brazil. Epidemiology \& Infection, London, v. 142, n. 1, p. 142148, 2014.

GARCIA, J. L.; NAVARRO, I. T.; OGAWA, L.; OLIVEIRA, R. C. Soroepidemiologia da toxoplasmose em gatos e cães de propriedades rurais do município de Jaguapitã, estado do Paraná, Brasil. Ciência Rural, Santa Maria, v. 29, n. 1, p. 99-104, 1999.

GRÖSZ, L. C. B.; FERNANDES, C. G. N.; MOURA, S. T.; TEIXEIRA, W. I. S. Inquérito Soroepidemiológico da Toxoplasmose canina no perímetro urbano de Cuiabá. Revista Brasileira de Medicina Veterinária, Rio de Janeiro, v. 24, n. 3, p. 118-121, 2002.

INSTITUTO BRASILEIRO DE GEOGRAFIA E ESTATÍSTICA - IBGE. Estimativas populacionais. Cuiabá: IBGE, 2010. Disponível em: <http://www.ibge. gov.br/cidadesat/topwindow.htm?1>. Acesso em: 15 maio 2011.

KOMPALIC-CRISTO, A.; BRITTO, C.; FERNANDES, O. Diagnóstico molecular da toxoplasmose: revisão. Revista Brasileira de Parasitologia Veterinária, Jaboticabal, v. 41, n. 4, p. 229-235, 2005.

LANGONI, H.; MODOLO, J. R.; PEZERICO, S. B.; SILVA, R. C.; CASTRO, A. P. B.; SILVA, A. V. da. Serological profile of anti-Toxoplasma gondii antibodies in apparently healthy dogs of the city of Botucatu, São Paulo State, Brazil. Journal of Venomous Animals and Toxins Including Tropical Diseases, Botucatu, v. 12, n. 1, p. 142-148, 2006.

MARTINS, S. C.; VIANA, J. A. Toxosplasmose - o que todo profissional de saúde deve saber. Revista Clínica Veterinária, São Paulo, v. 15, n. 3, p. 33-37, 1998. 
MINEO, T. W. P.; SILVA, D. A. O.; NÄSLUND, K.; JJÖRKMAN, C.; UGGLA, A.; MINEO, J. R. Toxoplasma gondii and Neospora caninum serological status of different canine populations from Uberlândia, Minas Gerais. Arquivo Brasileiro de Medicina Veterinária e Zootecnia, Belo Horizonte, v. 56, n. 3, p. 414-417, 2004.

MORETTI, L. D.; UENO, T. E.; RIBEIRO, M. R.; AGUIAR, D. M.; PAES, A. C.; PEZERICO, S. B.; SILVA, A. V. Toxoplasmose em cães co-infectados com o vírus da cinomose. Semina Ciências Agrárias, Londrina, v. 23, n.1, p. 85-91, 2002.

MOURA, A. B.; SOUZA, A. P.; SARTOR, A. A.; BELLATO, V.; TEIXEIRA, E. B.; PISETTA, G. M.; HEUSSER JUNIOR, A. Ocorrência de anticorpos e fatores de risco para infecção por Toxoplasma gondii em cães, nas cidades de Lages e Balneário Camboriú, Santa Catarina, Brasil. Revista Brasileira de Parasitologia Veterinária, Jaboticabal, v. 18, n. 3, p. 52-56, 2009.

REID, A. J.; VERMONT, S. J.; COTTON, J. A.; HARRIS, D.; HILL-CAWTHORNE, G. A.; NEN-WAISMAN, S. K.; LATHAM, S. M.; MOURIER, T.; NORTON, R.; QUAIL, M. A.; SANDERS, M.; SHANMUGAM, D.; SOHAL, A.; WASMUTH, J. D.; BRUNK, B.; GRIGG, M. E,; HOWARD, J. C.; PARKINSON, J.; ROOS, D. S.; TREES, A. J.; BERRIMAN, M.; PAIN, A.; WASTLING, J. M. Comparative Genomics of the Apicomplexan Parasites Toxoplasma gondii and Neospora caninum: Coccidia Differing in Host Range and Transmission Strategy. PLoS Pathogens, Georgia, v. 8, n. 3, p. 1-15, 2012.

ROMANELLI, P. P.; FREIRE, R. L.; VIDOTTO, O.; MARANA, E. R. M.; OGAWA, L.; PAULA, V. S. O. de; GARCIA, J. L.; NAVARRO, I. T. Prevalence of Neospora caninum and Toxoplasma gondii in sheep and dogs from Guarapuava farms, Paraná State, Brazil. Research in Veterinary Science, Kansas City, v. 82, n. 2, p. 202-207, 2007.
SAMBROOK, J.; FRITSCH, E. F.; MANIATIS, T. Molecular cloning: a laboratory manual. $2^{\text {th }}$ ed. New York: Cold spring Harbor Laboratory Press, Cold Spring Harbor, 1989. v. 1, 1626 p.

SANTOS, T. R.; COSTA, A. J.; TONIOLLO, G. H.; LUVIZOTTO, M. C. R.; BENETTI, A. H.; SANTOS, R. R.; MATTA, D. H.; LOPES, W. D.; OLIVEIRA, J. A.; OLIVEIRA, G. P. Prevalence of anti-Toxoplasma gondii antibodies in dairy cattle, dogs and humans from the Jauru micro-region, Mato Grosso state, Brazil. Veterinary Parasitology, Amsterdam, v. 161, n. 3-4, p. 324-326, 2009.

SILVA, A. V. da; GONÇALVES, G. F.; LÍVERO, F. A. R.; BOTTIN, J. M. P.; BELINATO, F. C.; BASTOS JÚNIOR, E. A.; SILVA, R. C.; LANGONI, H. Avaliação de fatores epidemiológicos na ocorrência de anticorpos contra Toxoplasma gondii em cães atendidos em um Hospital Universitário. Veterinária e Zootecnia, Botucatu, v. 16, n. 1, p. 239-247, 2009.

SOUZA, S. L. P.; GENNARI, S. M.; YAI, L. E. O.; D'AURIA, S. R. N.; CARDOSO, S. M. S.; GUIMARÃES JUNIOR, J. S. Occurrence of Toxoplasma gondii antibodies in sera from dogs of the urban and rural areas from Brazil. Revista Brasileira de Parasitologia Veterinária, Jaboticabal, v. 12, n. 1, p. 1-3, 2003.

SROKA, S.; BARTELHEIMER, N.; WINTER, A.; HEUKELBACH, J.; ARIZA, L.; RIBEIRO, H.; OLIVEIRA, F. A.; QUEIROZ, A. J.; ALENCAR JUNIOR, C.; LIESENFELD, O. Prevalence and risk factors of toxoplasmosis among pregnant women in Fortaleza, Northeastern Brazil. The American Journal of Tropical Medicine and Hygiene, New Orleans, v. 83, n. 3, p. 528-533, 2010. 
